\title{
Володина Е.C. \\ Президент Российской Федерации - верховный главнокомандующий вооруженными силами Российской Федерации
}

\author{
Пензенский государственный университет г. Пензы
}

(Россия, Пенза)

doi:10.18411/spc-20-11-2017-15

idsp: 000001:spc-20-11-2017-15

Главой Российской Федерации, гарантом суверенитета и защиты прав и свобод человека и гражданина является высшее должностное лицо, избираемое многонациональным народом - Президент Российской Федерации. Он имеет широкий ряд полномочий, осуществляет контроль и координацию всех общественных сфер жизни - политической, социальной, экономической и духовной. Президент Российской Федерации определяет направления внешней и внутренней политики, осуществляет надзор за всеми ветвями государственной власти, министерствами и ведомствами Российской Федерации.

Одна из особенностей конституционно - правового статуса Президента заключается в том, что при исполнении обязанностей главы государства, он исполняет обязанности Верховного главнокомандующего Вооруженными силами Российской Федерации. В случае агрессии против Российской Федерации либо непосредственной угрозы такой агрессии, глава государства вводит на территории Российской Федерации либо на отдельной ее территории военное положение.

Верховный главнокомандующий Вооруженными силами Российской Федерации - начальник вооруженных сил государства не только в военное, но и в мирное время. Верховным главнокомандующим является лицо, занимающее пост главы государства.

Мещеряков А.Н. дает следующую трактовку понятия Верховного главнокомандующего - «конкретное лицо, которое наделено большим количеством полномочий в сфере военного управления и которое осуществляет координацию абсолютно всего массива войск того или иного государства».

Хрулев А.В. считает, что Верховный главнокомандующий - «это лицо, осуществляющее руководство армией государства, а также учреждениями и организациями, направленными на поддержание защиты и суверенитета страны».

Зуйков А.В. как автор множества работ о статусе Верховного Главнокомандующего в годы Советского союза дает такое понятие данному институту - «это совокупность определённого рода обязательств, функций ответственности».

Изучив мнения известных правоведов и историков, можно сформулировать единое понятие Верховного главнокомандующего Вооруженными силами Российской Федерации - это должностное лицо, которое в соответствии с нормативно - правовыми актами осуществляет руководство Вооруженными силами Российской Федерации в военное и мирное время, определяет основные направления военной политики Российской Федерации и обеспечивает ее суверенность и безопасность.

На сегодняшний день Президент Российской Федерации представляет собой орган государственной власти, имеющий уникальный конституционно - правовой статус, который невозможно сравнить ни с одним другим статусом какого - либо иного органа государственной власти. Функции, осуществляемые главой государства, носят непосредственно исполнительный характер, либо максимально приближены к исполнительной ветви власти, но во всяком случае Президент не относится ни к какой из ее ветвей, а возвышается над ними, осуществляя координирующие функции.

В настоящее время нормативно - правовых актов, регулирующих деятельность главы государства достаточно велико и не всегда возможно сориентироваться в нормативной базе, контролирующей полномочия и функции Президента Российской 
Федерации. Решением данной проблемы может служить принятие федерального закона «О Президенте Российской Федерации».

В целях усовершенствования и закрепления правовой базы, регулирующей деятельность главы государства, предлагается принять новый федеральный закон «О Президенте Российской Федерации», который будет содержать в себе следующие нормы:

1. Понятие должности Президента Российской Федерации;

2. Требования, предъявляемые к кандидатуре на пост Президента Российской Федерации;

3. Порядок назначения выборов, выдвижения кандидатов, проведение предвыборной агитации, процесс проведения выборов, подведение итогов, деятельность Центральной Избирательной комиссии, подведение итогов и обнародование результатов голосования;

4. Присяга Президента Российской Федерации;

5. Взаимодействие Президента Российской Федерации с федеральными органами государственной власти;

6. Администрация Президента Российской Федерации;

7. Полномочия Президента Российской Федерации в экономической сфере;

8. Полномочия Президента Российской Федерации в социальной и духовной сферах;

9. Президент Российской Федерации как Верховный главнокомандующий Вооруженными силами Российской Федерации;

10. Деятельность Президента Российской Федерации в международных отношениях;

11. Законотворчество Президента Российской Федерации;

12. Гарантии, предоставляемые Президенту Российской Федерации;

13. Ответственность Президента Российской Федерации;

14. Должность исполняющего обязанности Президента Российской Федерации;

15. Прекращение полномочий Президентом Российской Федерации.

16. Регалии Президента Российской Федерации.

Вышеуказанный нормативно - правовой акт способствует более четкому группированию всех основных норм законодательства о Президенте Российской Федерации, послужит незаменимым источником для изучения деятельности Президента как в школьной программе, так и для абитуриентов.

Предлагается, что статья 9 «Президент Российской Федерации как Верховный главнокомандующий Вооруженными силами Российской Федерации» в Федеральном законе «О Президенте Российской Федерации» будет содержать в себе следующие нормы:

1. Верховный главнокомандующий Вооруженными силами Российской Федерации - высший руководитель Вооруженных сил Российской Федерации - Президент Российской Федерации.

2. Президент Российской Федерации осуществляет полномочия Верховного главнокомандующего Вооруженными силами Российской Федерации на основании Конституции Российской Федерации и иных нормативно правовых актов;

3. Верховный главнокомандующий Вооруженными силами Российской Федерации исполняет следующие полномочия:

А) Определяет основные направления внешней и внутренний военной политики государства;

Б) При достаточных основаниях вводит на территории Российской Федерации или на отдельных ее территориях военное или чрезвычайное положение; 
В) Осуществляет руководство Вооруженными силами Российской Федерации, определяет направления их действий, решает вопрос о применении мер Вооруженных сил Российской Федерации с использованием вооружения не по их предназначению;

Г) Вводит в действие нормативно - правовые акты военного времени и отменяет их действия;

Д) Утверждает уставы Вооруженных сил Российской Федерации, Министерства обороны Российской Федерации и Генерального Штаба Российской Федерации, воинских организаций и образований, планы вооружения и оборонно - промышленного комплекса;

Е) Упраздняет федеральные органы исполнительной власти;

Ж) Объявляет всеобщую либо частичную мобилизацию;

3) Утверждает планы ядерных и иных специализированных испытаний;

И) Утверждает перечень воинских должностей, указом Верховного главнокомандующего Вооруженными силами Российской Федерации назначает и освобождает с воинских должностей;

К) Согласует структуру и состав Вооруженных сил Российской Федерации;

Л) Принимает решение о дислокации и передислокации Вооруженных сил Российской Федерации;

М) Утверждает план гражданской обороны и положение о территориальной обороне;

Н) Ведет переговоры и подписывает международные договоры, касающиеся обороны и военной деятельности Российской Федерации;

О) Утверждает планы размещения объектов с ядерным оружием;

П) Издает указы о призыве граждан на военную службу, военные сборы, а также об увольнении с нее.

1. Верховный главнокомандующий Вооруженными силами Российской Федерации издает приказы и директивы.

2. Верховный главнокомандующий Вооруженными силами Российской Федерации в целях поощрения за заслуги перед Отечеством в исполнении воинского долга, укрепления обороноспособности государства, награждает грамотой или объявляет благодарность.

3. Эмблема Верховного главнокомандующего Вооруженными силами Российской Федерации - официальный символ Президента Российской Федерации как Верховного главнокомандующего Вооруженными силами Российской Федерации.

Эмблема помещается на знаках различия Верховного главнокомандующего Вооруженными силами Российской Федерации, на бланках грамот и благодарностей, а также на учреждаемых Верховным главнокомандующим знаков отличия. Эмблема может быть помещена на зданиях и сооружениях, документах, транспортном средстве или ином средстве передвижения, служащего для обеспечения деятельности Президента Российской Федерации как Верховного Главнокомандующего Вооруженными силами Российской Федерации.

Принятие Федерального закона «О Президенте Российской Федерации» означает новую ступень законодательного закрепления статуса и полномочий главы Российского государства. Данный закон отражает в себе все стороны деятельности Президента, его основные обязанности и характеристики конституционно - правового статуса, гарантии его деятельности и полномочия в различных сферах государственной власти.

Изучение военных полномочий Президента Российской Федерации носит более теоретический и научный характер, нежели практический. Редко на практике глава государства полностью реализует данные полномочия, но в связи с международными событиями - гражданскими воинами, многочисленными атаками террористов и 
деятельностью экстремистов, нападениями на мирных жителей, полномочия Президента России в данной области с каждым годом становятся все более широкими, поэтому деятельность главы государства в этой сфере в настоящее время является актуальной и значимой.

Таким образом, нормы, принятые в федеральном законе «О Президенте Российской Федерации» четко определят и закрепят конституционно - правовой статус главы государства, его полномочия в политической, социальной, экономической и военной сферах жизни граждан, сконцентрировав в себе основные положения, касающиеся внутригосударственной и международной деятельности Президента Российской Федерации.

$$
* * *
$$

1. Конституция Российской Федерации от 12 декабря 1993 года (принята всенародным голосованием 12.12.1993) (с учетом поправок, внесенных Законами РФ о поправках к Конституции РФ от 30.12.2008 № 6-ФКЗ, от 30.12.2008, № 7-ФКЗ, от 05.02.2014, № 2-ФКЗ, от 21.07.2014 № 11-ФКЗ) // Законодательство. - 18.05.2017. - № 10;

2. Федеральный закон от 12.02.1998 года № 28 - Ф3 «О гражданской обороне» (в редакции от 20.12.2015) [Электронный pecypc]URL: http://www.consultant.ru/document/cons_doc_LAW_17861/ (дата обращения 17.05.2017);

3. Федеральный конституционный закон от 30.01.2002 года № 1- ФКЗ «О военном положении» $\begin{array}{lllll}\text { (редакция } & \text { от } & 01.07 .2017) & \text { [Электронный }\end{array}$ http://www.consultant.ru/document/cons_doc_LAW_35227/(дата обращения 09.09.2017);

4. Федеральный закон от 30.05.2001 года № 3 - ФКЗ «О чрезвычайном положении» (в редакции от 30.07.2016) [Электронный pecypc] URL: http://www.consultant.ru/document/cons_doc_LAW_31866/(дата обращения 15.08.2017);

5. Указ Президента РФ «Об Администраций Президента Российской Федерации» от 25 марта 2004 года № 400 // Российская газета. № 63.;

6. Елисеев Б.Н. Становление института президентства. - М.: НОРМАТ, 2015. - 318 с.;

7. Зуйков А.В. Верховный главнокомандующий в годы Великой Отечественной Войны 1941-1945 гг. М.: Ральф, 2009. -421 с.;

8. Ковалев А.М. Институт Президента в системе разделения властей: Дис. ... канд. юрид. наук. - М., 2015. - 387 c.;

9. Мещеряков А.Н. Правовой статус Президента Российской Федерации. - М.: Омега, 2016. - 198 с.;

10. Хрулев А.В. Ставка Верховного главнокомандующего Вооруженными силами Российской Империи. - М.: Спектра, 2013. - 187 с.

\section{Удалов Д.Э.}

\section{К вопросу о комплексном правовом регулировании туристских правоотношений}

Московский государственный институт индустрии туризма имени Ю.А. Сенкевича doi:10.18411/spc-20-11-2017-16

(Россия, Москва) idsp: 000001:spc-20-11-2017-16

\section{Аннотация}

В статье рассматриваются вопросы правового регулирования туристских отношений. Показан их комплексный характер, посредствам взаимодействия с публичными и частными отраслями российской системы права.

Ключевые слова: система права, отрасль права, правоотношения, правовое регулирование туризма, туристские правоотношения.

Все сферы жизни общества подчинены правовому регулированию, не является исключением и туристская деятельность. Туризм является важной составляющей экономического развития страны. В туристской деятельности участвует большое количество субъектов экономических отношений - юридических лиц и индивидуальных предпринимателей (туроператоров, турагентов, экскурсионных бюро, организаций культуры, гостиничных предприятий, организаций общественного 